Karstenia 45: 63-68, 2005

\title{
Geastrum rufescens in the Åland Islands, SW Finland
}

\author{
RALFCARLSSON and CARL-ADAM HÆGGSTRÖM
}

CARLSSON, R. \& HÆGGSTRÖM, C.-A. 2005: Geastrum rufescens in the Alland Islands, SW Finland. - Karstenia 45: 63-68. Helsinki. ISSN 0453-3402.

Geastrum rufescens was found in four localities on the Åland Islands in 2002 and 2004. The species has not been recorded earlier on Åland, although numerous finds are known from the adjacent parts of Sweden, e.g. Uppland and Gotland, and a few from mainland Finland. The distribution of G. rufescens in the Nordic countries is briefly outlined and its ecology is discussed.The four localities on Aland with the accompanying vascular plant flora and the soil properties are described. The properties which distinguish G. rufescens are discussed.

Key words: Åland Islands, calcium, SEM, soil, spores, vascular plant flora

Ralf Carlsson, Husö Biological Station (Åbo Akademi University), AX-22220 Emkarby, Åland, Finland. Correspondence address Högbackagatan 10, AX-22100 Mariehamn, Aland, Finland

Carl-Adam Haggström, Department of Biological and Environmental Sciences, P.O.Box 65 FI-00014 University of Helsinki, Finland

\section{Introduction}

On 29 September, 2002, Mr. Bill and Mrs. Inger Flöjt found earthstars at their summer cottage in Möskatan, village of Kungsö in the municipality of Jomala. They collected three sporocarps, and the local newspaper 'Åland' published a photograph of one of them with short texts (Carlsson 2002a, 2002b). The author RC visited the locality at Möskatan, made annotations of the vascular plant flora and took a soil sample for analysis. A few days later, an anonymous lady informed the author RC that earthstars were growing in the village of Mörby in the municipality of Hammarland. The author RC visited the locality on 6 October 2002, and found several sporocarps (Fig. $1)$, three of which were collected. The vascular plants were recorded and a soil sample was taken.

In the autumn of 2004, an extraordinarily good year for earthstars in Alland, two more localities came to our knowledge, namely in Lemland: Herrö Nature Reserve, 24 Sept. 2004, and in Lem- land, Järsö Bergö, 5 Oct. 2004 (Anonymous 2004). The author RC made recordings of the vascular plant flora in both localities and took soil samples.

The collected specimens from these localities were identified as Geastrum rufescens Pers. : Pers., a species not previously recorded in the Åland Islands (Hæggström 1997a). This is a rare species in Finland (Sunhede 1989, 1997, Ulvinen 1994). Besides the two records from Ta, Lahti and Ab, Karkkila reported by Sunhede (1989; specimens preserved in $\mathrm{H}$ ), the following have been seen by the author $\mathrm{CAH}$ :

Regio aboënsis. Lohja, Lohjansaari, Hermala, at a road margin, Grid $27^{\circ}$ E: 6683:326, 25 Sept. 1991 Ilkka Kytövuori (to be included in $\mathrm{H}$ ); Kirkniemi, near the crossroads of Tiilitie and Kuninkaantie, at a ruin of concrete in a grass-herb forest, Grid $27^{\circ} \mathrm{E}$ : 6677:332, 23 Sept. 2001 Johanna von Weissenberg (TURA). Karelia australis. Vehkalahti, Ristiniemi, on ruins of an old building about $25 \mathrm{~m}$ from the seashore in grass-herb forest at Haminan lahti bay; pine, rowan, birch, alder, apple tree, roses; 37 sporocarps observed, Grid $27^{\circ} \mathrm{E}: 6715: 511$, 
25 Oct. 1983 Aino Pakkala (H). Tavastia australis. Asikkala, Vääksy, Aurinkovuori, on the earth bank of the shooting range, at the base of Sambucus racemosa, about 20 last year sporocarps, Grid $27^{\circ} \mathrm{E}$ : 6786:419, 7 May 2001 Veli Haikonen 20520 (H); about 20 gastrocaps in a dense cluster together with Sambucus, Urtica and Rubus, 17 Sept. 2001 Veli Haikonen 20763 (H).

Geastrum rufescens is a rather southerly species in the Nordic countries and the Baltic area (distribution chiefly according to Sunhede 1989). Only one find in Sweden and three in Finland are located north of the hemiboreal zone, the northernmost being the locality in Ta, Asikkala: Vääksy at latitude $61^{\circ} 11^{\prime}$ N. G. rufescens is common or fairly common in eastern Sweden, especially in Uppland and Södermanland and on the limestone island of Gotland. In Estonia, the species has been found in two localities on the limestone island of Hiiumaa and one locality in the limestone isand of Saaremaa; two further finds are known from the eastern part of mainland Estonia (Järva 1999). A few finds are known from northeastern Germany and Denmark. Only one find is known from Norway.

Geastrum rufescens is not included in the Red List of Finland (Rassi et al. 2001) and Denmark (DMS 2004) and is regarded as not threatened in Sweden (Gärdenfors 2000). It is classified as endangered in Norway (NRL 2004) and rare in Estonia (Järva 1999, ERL 2001-2002).

\section{Material studied}

The following material was studied: Alandia. Jomala, Kungsö, Möskatan, partly cleared mixed forest near the sea shore, 3 ripe sporocarps, Grid. $27^{\circ}$ E: 66851:1010, 29 September 2002 Bill \& Inger Flöjt (H). Hammarland, Mörby, under a single spruce on the side of a road, with thinned pine forest on the west side of the road, 3 ripe sporocarps, Grid. 27 ${ }^{\circ}$ E: 67025:0974, 6 October 2002 Ralf Carlsson (H). Lemland, Herrö, grass-herb wood near the road, 2 sporocarps seen, one collected, Grid $27^{\circ}$ E: 66706:1198, 24 September 2004 Ralf Carlsson (H). Lemland, Järsö, Bergö, grass-herb forest in the seashore Alnus glutinosa fringe at the edge of a mown lawn by Mr. Edgar and Mrs. Astrid Fridlund's house, three sporocarps seen, none collected Grid 27 E: 66777:1095 (Fig. 2).

A WILD M 20 microscope was used for light microscopy. Spores were studied at $2250 \times$ magnification. Fifty spores from one sporocarp from each locality were measured in Melzer's reagent. The diameter of the spores including their processes could be measured with an accuracy of about $0.4 \mu \mathrm{m}$.

Spores of the sporocarps collected in 2002 were also examined by scanning electron microscopy (SEM) at the EM Unit, Institute of Biotechnology, University of Helsinki. Air dried spores were fixed to specimen stubs either with RX-glue (cf. Sunhede 1989) or small pieces of adhesive tape and then coated with platinum in a vacuum. They were observed in a Zeiss DSM 960 scanning electron microscope at an accelerating voltage of $5-10 \mathrm{kV}$. The size of the spores (including processes) and their processes were measured from SEM images, too.

Soil samples from the humus layer and the uppermost underlying mineral soil were analysed at the laboratory of The Agri- and Horticultural Research Station of the Alland Islands. The samples were extracted for one hour in a solution of ammonium acetate $(\mathrm{pH} 4.65)$ and analysed for exchangeable $\mathrm{Ca}^{++}, \mathrm{Mg}^{++}, \mathrm{K}^{+}, \mathrm{PO}_{4}{ }^{2-}$ and $\mathrm{NO}_{3}$ with atomic absorption spectrophotometry. Further ${ }^{3}$, the $\mathrm{pH}$ was measured on $25 \mathrm{ml}$ of dried, ground soil which was mixed with $62.5 \mathrm{ml}$ of ion-exchanged water. The measuring took place 17 hours later.

The nomenclature of the vascular plants is according to the Finnish Field Flora (Hämet-Ahti et al. 1998).

\section{Results}

\section{Sporocarps and spores}

The species Geastrum rufescens is rather easy to recognise because of the reddish colour of the fleshy pseudoparenchymatous layer of the exoperidium (Figs. 1 and 2). This colour is usually persistent in dried sporocarps, too. The stalk of the endoperidium of the six sporocarps studied is very short $(1-2 \mathrm{~mm})$. The peristome is fibrillose and indistinctly delimited.

The size of the six sporocarps varied as follows: - width of expanded exoperidium: Kungsö, 53 mm - 75 mm; Mörby, 81 mm - 93 mm; Herrö $100-110 \mathrm{~mm}$

- number of exoperidium rays: Kungsö, 7-8; the rays recurved towards the endoperidial body as the sporocarps dried; Mörby, 6-7; Järsö 57; Herrö 6-8; the rays recurved towards the endoperidial body as the sporocarp dried

- size of endoperidium (diameter and the height from the base to the peristome tip): Kungsö, diameter 18-25 mm, height 12-14 mm; Mörby, diameter 23-26 mm, height 17-18 mm; Herrö diameter $32 \mathrm{~mm}$, height $17 \mathrm{~mm}$.

The size (minimum measurement - mean - maximum measurement) of the spores studied in Melzer's reagent was:

- Kungsö: $4.4-5.12-5.6 \mu \mathrm{m}(\mathrm{n}=50)$

- Mörby: $4.4-5.23-5.6 \mu \mathrm{m}(\mathrm{n}=50)$

- Herrö: 4.0 - 4.26 - $4.8 \mu \mathrm{m}(\mathrm{n}=50)$.

The size (minimum measurement - mean - maximum measurement) of the spores measured on SEM images was: 
- Kungsö: $3.70-4.24-4.85 \mu \mathrm{m}(\mathrm{n}=57)$

- Mörby: $3.68-4.22-4.56 \mu \mathrm{m}(\mathrm{n}=44)$.

The processes of the spores of Kungsö and Mörby are up to $0.75 \mu \mathrm{m}$ high, conical or columnar with rounded or planar tips. The planar tips are occasionally widened. Seen from the tip the processes are rounded or mostly irregularly angular. Some of them are confluent forming short windling ridges or clumps of few connected processes.

\section{Localities and accompanying vascular plants}

The locality in Kungsö Möskatan is a partly cleared mixed forest between a summer cottage and the adjacent sea shore. Four sporocarps, one of which was damaged and therefore not collected, grew on the humus at a small path near the summer cottage. The distance to the sea shore is less than ten metres and the elevation is approximately 1 metre above sea level.

The tree layer comprises the common conifer species Picea abies, Pinus sylvestris and the common deciduous species Alnus glutinosa and Betula pendula. A few shrubs of Ribes alpinum and seedlings of Sorbus aucuparia and Rosa sp. occur, too.

Thirty taxa of herbs and grasses, most of them everyday and common species in the Aland Islands, were noted. Some of the species, such as Angelica archangelica ssp. litoralis, Leymus arenarius, Potentilla anserina and Valeriana officinalis, are typical of sea shores. Among the common woodland and meadow species Anthriscus sylvestris, Carex digitata, Deschampsia cespitosa, D. flexuosa, Fragaria vesca, Hepatica nobilis, Oxalis acetosella and Veronica officinalis can be mentioned. A few weedy plants, such as Cirsium vulgare, Plantago major ssp. major, Stellaria media and Taraxacum sp., occur. This is obviously a result of the clearing of the formerly very dense forest and the activity of man in the vicinity of the summer cottage. Only very few calciphilic species, according to Eklund (1946), were found. Of these, Rubus caesius is the only strictly limestone dependent species. It is quite common in the black alder belt on stony and bouldery sea shores in Åland.

The locality in Mörby is located about $25 \mathrm{~m}$ above the sea level and almost $2 \mathrm{~km}$ from the nearest seashore in a rather homogeneous pine forest, which has recently been thinned. The sporocarps grew close to a path on an area of about one square metre on the spruce needle litter under a large spruce. Nine sporocarps were seen, of which three were collected. In addition to the dominating $P i$ cea abies and a few Pinus sylvestris, a Betula pendula and a Malus sylvestris grew on this locality. A few seedlings of Acer platanoides and one small Sorbus hybrida were also seen.

The herb and grass flora is poor in species with only 15 taxa noted, most of them common forest and meadow species, such as Carex digitata, Dactylis glomerata, Deschampsia cespitosa, D. flexuosa, Fragaria vesca, Oxalis acetosella, Vaccinium vitis-idaea and Veronica officinalis. Only two moderately calciphilic herb species, namely Geranium sanguineum and Primula veris, were found.

The locality in Herrö is located in the southern part of the nature reserve, in a lax deciduous stand between the roads about $2 \mathrm{~m}$ above the sea level and $100 \mathrm{~m}$ from the seashore. The main tree layer comprises Betula pendula and Fraxinus excelsior. The field layer was rather heavily grazed by sheep and poor in species; only ten species were noted, all of them typical of deciduous woods and meadows: Anthriscus sylvestris, Dactylis glomerata, Fragaria vesca, Geranium pusillum, Geum urbanum, Glechoma hederacea, Hepatica nobilis, Primula veris, Silene dioica and Urtica dioica. Of these, Primula veris was the only calciphilic species.

The locality in Järsö Bergö was located only some metres above the sea level in the Alnus glutinosa fringe between a mown lawn and the seashore. Other woody species noted were Betula pendula, Corylus avellana, Fraxinus excelsior, Hippophaë rhamnoides, Picea abies, Prunus padus, Ribes alpinum, Rosa dumalis, Sorbus hybrida, Taxus baccata and Viburnum opulus. The field layer comprised 19 species common to deciduous woods and meadows, such as Achillea millefolium, Anemone nemorosa, Anthriscus sylvestris, Centaurea jacea, Cerastium fontanum ssp. vulgare, Dactylis glomerata, Filipendula ulmaria, Fragaria vesca, Hepatica nobilis, Melica nutans, Ranunculus auricomus coll., Silene dioica and Viola riviniana. A few weedy species, Cirsium arvense, Stellaria media and Taraxacum sp., were also found. The calciphilic species include Primula veris, Rubus caesius and Taxus baccata.

\section{The soil}

The soil at Möskatan in Kungsö, Herrö and Järsö Bergö are young as they have developed during 


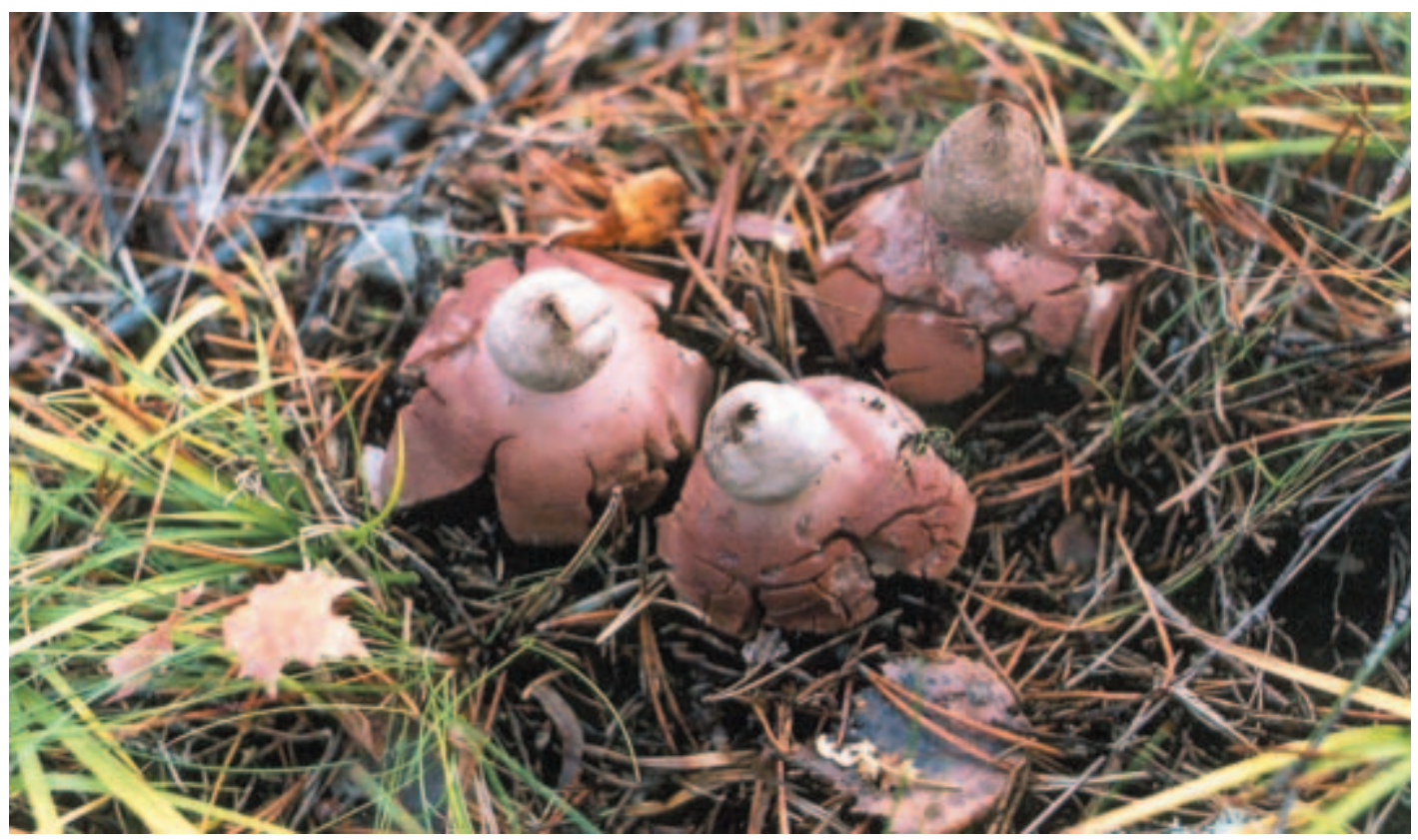

Fig. 1. Three sporocarps of Geastrum rufescens in situ in Mörby. Litter of pine needles and leaves of maple and birch partly cover the ground. Small tufts of Carex digitata are also seen. Photo: Ralf Carlsson.

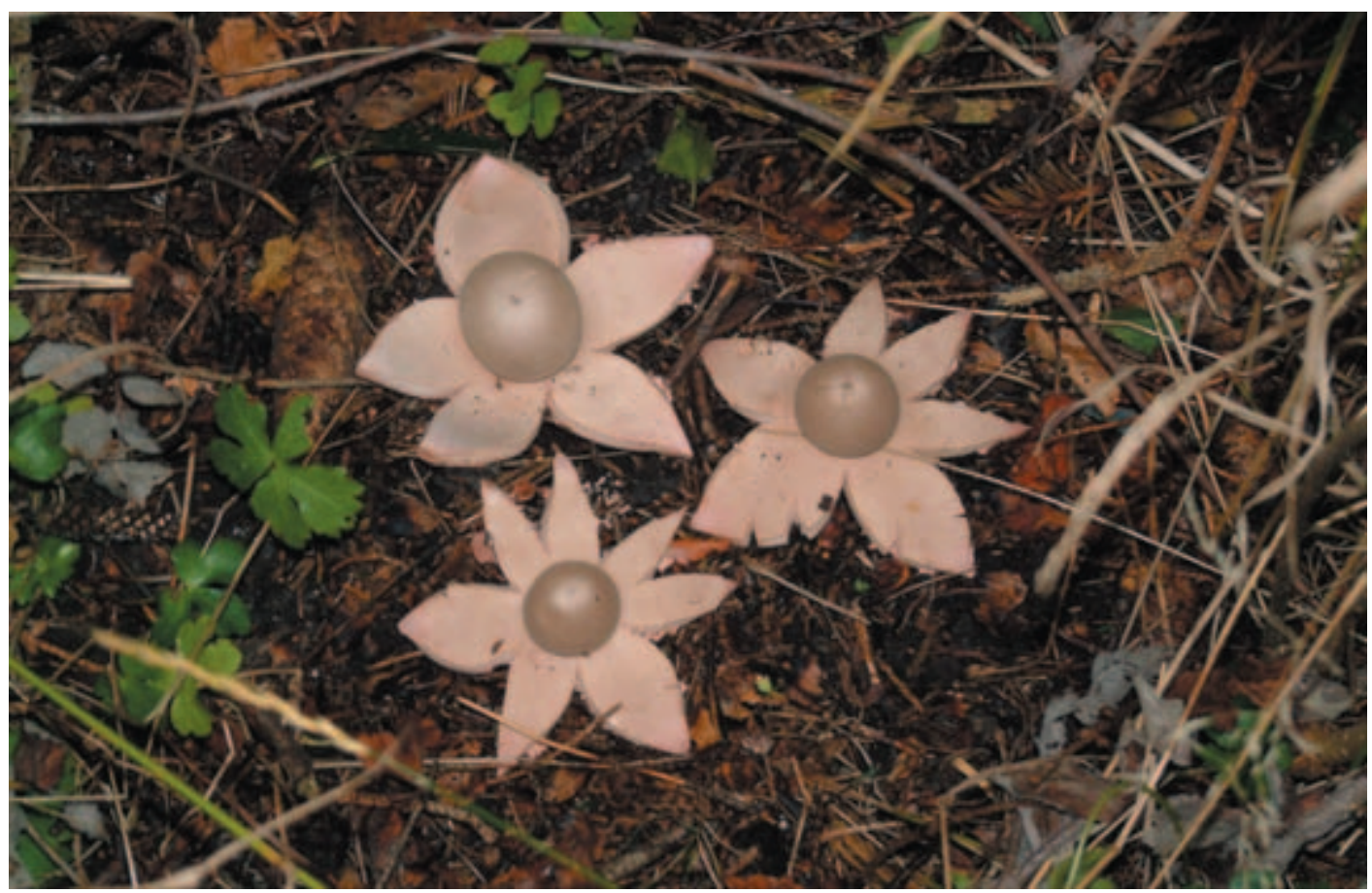

Fig. 2. Three sporocarps of Geastrum rufescens in situ in Järsö Bergö. Litter partly covers the ground and leaves of, e.g. Oxalis acetosella, Sanicula europaea and Filipendula ulmaria are seen. Photo: Jarl-Eric Holm. 
the last two or three centuries due the the land uplift phenomenon (Winterhalter et al. 1981). The humus is a thin mull-type humus (or mull-like moder according to Kubiëna 1953; cf. Hæggström 1983) overlying fine sand. The values of $\mathrm{pH}$ and exchangeable calcium are unusually high in Kungsö and comparably high in Herrö and Järsö Bergö (Table 1). The values of exchangeable $\mathrm{Mg}^{++}, \mathrm{K}^{+}$,
$\mathrm{PO}_{4}{ }^{2-}$ and $\mathrm{NO}_{3}^{-}$are quite common for the mulltype soils of Aland, but $\mathrm{Mg}^{++}, \mathrm{K}^{+}$and $\mathrm{PO}_{4}{ }^{2-}$ in Järsö, which are high (cf. Hæggström 1983).

The soil in Mörby is a weak podzolic soil with a thin mor layer on sandy glaciofluvial material. The values of $\mathrm{pH}$ and exchangeable nutrients are quite common for such soils on Åland.

Table 1. Soil properties at the four localities of Geastrum rufescens. Two samples, one from the uppermost soil and one from $10 \mathrm{~cm}$ depth were measured in Järsö Bergö. NM = not measured.

\begin{tabular}{lllll}
\hline & Kungsö & Mörby & Herrö & Järsö Bergö \\
\hline $\begin{array}{l}\text { Mineral soil } \\
\text { Humus content }\end{array}$ & $\begin{array}{l}\text { fine sand } \\
\text { poor in humus }\end{array}$ & $\begin{array}{l}\text { sandy glaciofluvial } \\
\text { material } \\
\text { rich in humus }\end{array}$ & $\begin{array}{l}\text { fine sand } \\
\text { rich in humus }\end{array}$ & $\begin{array}{l}\text { fine sand } \\
\text { poor in humus }\end{array}$ \\
\hline $\mathrm{pH}$ & 7.8 & 5.9 & 6.6 & $5.6 ; 5.8$ \\
$\mathrm{Ca}^{++} \mathrm{mg} / \mathrm{l}$ & 10850 & 1190 & 3009 & $3692 ; 5120$ \\
$\mathrm{Mg}^{++} \mathrm{mg} / \mathrm{l}$ & 119 & 120 & 204 & $505 ; 500$ \\
$\mathrm{~K}^{+} \mathrm{mg} / \mathrm{l}$ & 51 & 96 & 93 & $238 ; 29$ \\
$\mathrm{Mg}: \mathrm{Ca}$ & 0.011 & 0.101 & 0.068 & $0.137 ; 0.098$ \\
$\mathrm{Mg}: \mathrm{K}$ & 2.34 & 1.25 & 2.19 & $2.12 ; 17.06$ \\
$\mathrm{Pmg} / \mathrm{l}$ & 8.1 & 2.0 & 6.0 & $63.0 . ; 9.0$ \\
$\mathrm{Nitrate-N} \mathrm{mg/l}$ & 6 & $\mathrm{NM}$ & $\mathrm{NM}$ \\
\hline
\end{tabular}

\section{Discussion}

According to Sunhede (1989), Geastrum rufescens is a very variable species concerning size, number of exoperidial rays and endoperidium. The most reliable character seems to be the reddening of the pseudoparenchymatous layer of the exoperidium.

The species which perhaps resembles G. rufescens most is G. coronatum Pers., a species not found hitherto in Finland. This species is hygroscopic and thus the false hygroscopic character which occasionally occurs in G. rufescens may cause confusion. Our sporocarps from Möskatan and Herrö show this false hygroscopic character. However, among other things, the reddish tint of the exoperidium, the rather light brown endoperodium and the ornamentation of the spores are typical properties of G. rufescens. The endoperidium lacks the reddish tint, the endoperidium is dark grey or almost black, and the ornamentation of the spores of G. coronatum comprises wart-like processes which may be confluent. The spores of G. coronatum in the SEM pictures in Sunhede (1989, Fig. 60) show chiefly confluent, partly warty processes, and they differ substantially from the spores of our material from Möskatan and Mörby.
Geastrum rufescens has also been confused with G. fimbriatum Fr. The lack of the reddish tint of the exoperidium and the small spores (3-4 $\mu \mathrm{m}$ in the light microscope in lactophenol or Melzer's reagent) should be characteristics that quite easily will distinguish G. fimbriatum from G. rufescens.

Sunhede $(1989,1997)$ reports that the spores are 5-6 $\mu \mathrm{m}$ in diameter. His measurements were made on spores examined with the light microscope in $2 \% \mathrm{KOH}$, Melzer's reagent and lactophenol with cotton blue. The size of the spores of our specimens measured in Melzer's reagent are somewhat smaller; the mean values are greater than 5 $\mu \mathrm{m}$ in the gastrocarps from Möskatan and Mörby, but only between 4.0 and $4.8 \mu \mathrm{m}$ in the gastrocarp from Herrö.

The spores measured on SEM images were much smaller; the means were 4.22 and $4.24 \mu \mathrm{m}$. However, the diameters of two spores in Sunhede's (1989) SEM Fig. 160 are only 3.75 and 4.08 $\mu \mathrm{m}$, and so accord with our measurements. In a study on Bovista pusilliformis (Kreisel) Kreisel (Hæggström 1997b), the spores measured were on average larger in Melzer's reagent than in lactophenol, a feature also seen in other Lycoper- 
daceae spores. Spores measured on SEM photographs were even smaller. Thus spores studied in liquid reagents are obviously larger than dry ones (Hæggström 1997b).

Geastrum rufescens has been found in the Nordic countries in coniferous and deciduous woods, on open grazed fields on sandy calcareous soils and on sites influenced by man (Sunhede 1989). According to Sunhede (1989), G. rufescens was not found on the more acid sandy or moraine soils of southern Sweden. The species shows, on the contrary, a strong affinity to the calcareous areas of, e.g. eastern Sweden including the limestone islands of Gotland and Öland. The two Estonian localities in Sunhede's (1989) distribution map are in limestone islands, too. Both localities of Geastrum rufescens in the Lohja area on mainland Finland are situated in an area rich in calcareous habitats. Thus, G. rufescens may be regarded as a moderately calciphilic species.

The locality at Möskatan in Kungsö has an unusually high content of exchangeable calcium, whereas the calcium content in Herrö and Järsö Bergö is high and in Mörby moderate. The high calcium content at Möskatan, Herrö and Järsö Bergö is reflected in some calciphilic vascular plant species, whereas only very few calciphilic species occur in Mörby. Herrö is one of the very species rich spots of the Åland Islands; many calciphilic species occur, such as Agrimonia procera, Avenula pratensis, Cephalanthera longifolia, Dactylorhiza sambucina, Geranium sanguineum, Helianthemum nummularium, Orchis mascula, Rhamnus cathartica and Rubus caesius.

It is possible, though, that the soils of Mörby are more rich in calcium than it appears from our single soil sample. At a distance of only about $100 \mathrm{~m}$ to the north is a shell gravel deposit (Carlsson 2003), and it is possible that calcium-rich shells are mixed in the mineral soil of the locality. Further, a locality of Cypripedium calceolus occurs only about $250 \mathrm{~m}$ from the locality of $G$. rufescens.

Acknowledgements: We are indebted to Mr. Bill and Mrs. Inger Flöjt for the information of Geastrum rufescens growing at their summer cottage and to Mr. Jarl-Eric Holm, who let us use his photograph of G. rufescens from Järsö.

\section{References}

Anonymous 2004: Läsarbilden. - Åland 113(193): 24. (6.10.2004.)
Carlsson, C. 2002a: Tvåstjärnigt i svampvärlden. - Åland 111(189): 15. (1.10.2002.)

Carlsson, C. 2002b: Rodnande ny stjärna på Åland. Åland 111(238): 15. (10.12.2002.)

Carlsson, R. 2003: Shore displacement and possible Littorina-transgressions as inferred from shell gravel deposits on the Aland Islands, SW Finland. - Geogr. Ann. 85: 205-209.

DMS 2004: Danish Mycological Society, Red List of fungi. - http://www.svampe.com/

Eklund, O. 1946: Über die Kalkabhängigkeit der Kormophyten SW-Finnlands. - Memoranda Soc. Fauna Flora Fennica 22: 166-187.

ERL 2001-2002: Punane Raamat, seened. (Estonian Red List of fungi.) - http://www.zbi.ee/punane/liigid/ seened.html

Gärdenfors, U. (ed.) 2000: Rödlistade arter i Sverige The 2000 Red List of Swedish species. - ArtDatabanken, SLU, Uppsala.

Hæggström, C.-A. 1983: Vegetation and soil of the wooded meadows in Nåtö, Åland. - Acta Bot. Fennica 120: $1-66$.

Hæggström, C.-A. 1997a: The Gasteromycetes of the Aland Islands, SW Finland: an annotated checklist. Karstenia 37: 11-18.

Hæggström, C.-A. 1997b: Bovista pusilliformis found in Finland. - Memoranda Soc. Fauna Flora Fennica 73: 59-64.

Hämet-Ahti, L., Suominen, J., Ulvinen, T. \& Uotila, P. (eds.) 1998: Retkeilykasvio (Field Flora of Finland), Ed. 4. - Finnish Museum of Natural History, Botanical Museum. Helsinki. 656 pp.

Järva, L. 1999: Geastrum rufescens Pers. - In: Parmasto, E. (ed.), Distribution maps of Estonian fungi 2. Protected species and species of the Estonian Red Data Book. Distribution Atlas of Estonian Fungi 2, nr. 63. Tartu.

Kubiëna, W. L. 1953: Bestimmungsbuch und Systematik der Böden Europas. Illustriertes Hilfsbuch zur leichten Diagnose und Einordning der wichtigsten europäischen Bodenbildungen unter Berücksichtigung ihrer gebräuchlichsten Synonyme. - Ferdinand Enke Verlag, Stuttgart. 392 pp., 26 plates.

NRL 2004: The Mycological Herbarium, Oslo. Taxa in the mycological herbarium. - http://www.toyen.uio.no/ botanisk/botmus/sopp/redalpha.htm

Rassi, P., Alanen, A., Kanerva, T. \& Manerkoski, I. (eds.) 2001: Suomen lajien uhanalaisuus 2000. (The 2000 Red List of Finnish species.) - Ympäristöministeriö \& Suomen ympäristökeskus, Helsinki. 432 pp.

Sunhede, S. 1989: Geastraceae (Basidiomycotina). Morphology, ecology, and systematics with special emphasis on the North European species. - Synopsis Fungorum 1: 1-534. Fungiflora, Oslo.

Sunhede, S. 1997: Geastraceae Corda. - In: Hansen, L. \& Knudsen, H. (eds.), Nordic Macromycetes 3: 341345. Nordsvamp, Copenhagen.

Ulvinen, T. 1994: Suomen uhanalaiset kupusienet. Sienilehti 46: 69-89.

Winterhalter, B., Flodén, T., Ignatius, H., Axberg, S. \& Niemistö, L. 1981: Geology of the Baltic Sea. - In: Voipio, A. (ed.), The Baltic Sea: 1-121. Elsevier Oceanography Series 30, Amsterdam, Oxford \& New York. 